\title{
The ultrasound technology for modifying enzyme activity
}

\author{
Meliza Lindsay Rojas; Júlia Hellmeister Trevilin; Pedro Esteves Duarte Augusto*
}

Department of Agri-food Industry, Food and Nutrition (LAN), Luiz de Queiroz College of Agriculture (ESALQ), University of São Paulo (USP), Piracicaba, SP, Brazil.

Received May 17, 2016. Accepted Jun 22, 2016.

\begin{abstract}
Enzymes are protein complexes compounds widely studied and used due to their ability to catalyze reactions. The food processing mainly aims the inactivation of enzymes due to various undesirable effects. However, there are many processes that can be optimized by its catalytic activity. In this context, different technologies have been applied both to inactivate or to improve the enzymes efficiency. The Ultrasound technology emerges as an alternative mainly applied to achieve the enzyme inactivation. On the contrary, very few investigations show the ability of this technology under certain conditions to achieve the opposite effect (i.e. increase the catalytic activity of enzymes). The objective of this study was to correlate the ultrasonic energy delivered to the sample $(\mathrm{J} / \mathrm{mL})$ with the residual enzymatic activity and explain the possible mechanisms which results in the enzymatic activation/inactivation complex behavior. The activity of POD in coconut water was evaluated as a model. The enzymatic activity initially increased, followed by reduction with a trend to enzyme inactivation. This complex behavior is directly related to the applied ultrasonic energy and their direct mechanical effects on the product, as well as the effect in the enzymatic infinite intermediate states and its structural conformation changes. The obtained results are useful for both academic and industrial perspectives.
\end{abstract}

Keywords: peroxidase(POD), enzymatic activity, enzymatic structural conformation, ultrasound technology, coconut water.

\section{Introduction}

The enzyme-catalysed reactions are important in pharmaceutical, chemical, non-alimentary and alimentary industry. It is important during the processing and preservation of food, since the activity of enzymes includes undesirable reactions such as browning, rancidity, discoloration, loss of texture, among others. In this case, it is necessary to inactivate the enzymes. However, there are enzymes that catalyse desirable reactions, such as that used for hydrolysis, clarifying or to soften meat. Traditional thermal methods such as sterilization, pasteurization, precooking or blanching are the methods most known and used by the food industry for the inactivation of enzymes, although many new technologies are also studied and applied. Biotechnological techniques and also some innovative technologies are also

* Corresponding author

E-mail: pedro.ed.augusto@usp.br (P.E.D. Augusto). used to improve and increase the enzymatic efficiency. In fact, the ultrasound technology is gaining importance. There are many studies of ultrasound application to achieve enzyme inactivation, such as for lipases, proteases, peroxidase (POD), polyphenol-oxidase (PPO), polygalacturonase (PG), pectinesterase, pectinmethylesterase (PME), ascorbate peroxidase (APx) (Costa et al., 2013; Huang et al., 2015; Tiwari et al., 2009; Vercet et al., 2001). On the other hand, few works demonstrate the capacity of these technology to enhance the enzyme activities.

It is difficult to identify the specific enzyme mechanism during sonication, which could be due to a singular or combination of several chemical and physical effects occurring simultaneously (Rawson et al., 2011).

In this work, the coconut water is 
considered as a model product to be investigated because despite the different studies that have been performed using different technologies (such as the conventional thermal process (Fontan et al,. 2012; Murasaki-Aliberti et al., 2009; Tan et al., 2014b), membranes (Das Purkayastha et al., 2012; Nakano et al., 2011), use of additives (Abreu y Faria, 2007; Pereira et al., 2013), microwave (Matsui et al., 2007; Matsui et al., 2008) and ultraviolet radiation (Augusto et al., 2015), problems related with its enzyme stability (POD and PPO) are still observed. Since the ultrasound technology application in coconut has not been studied yet, this work evaluated the peroxidase (POD) enzymatic behaviour during the ultrasonic processing, considering two equipment with different frequency and acoustic intensity.

\section{Material and methods}

\subsection{Raw material preparation}

Coconut water (pH: $5 \pm 0.4$; ${ }^{\circ}$ Brix: $5 \pm 0.8$ ) was obtained of green coconuts from the local market (CEASA/Piracicaba, SP, Brazil). After cleaning and sanitizing, the mesocarp of coconuts was drilled with a special knife to extract their water. The water was filtered to remove particulate matter. The product obtained of different fruits was mixed, portioned and rapidly frozen $\left(\sim-20{ }^{\circ} \mathrm{C}\right)$ for all future processes and analyses.

\subsection{Ultrasound processing}

The coconut water was processed using two ultrasonic equipment (probe and bath). The sample $(105 \mathrm{~mL})$ was processed for 20 min using an ultrasonic probe (ECOSONIC, QR1000 Model, Brazil) with a frequency of $20 \mathrm{kHz}$, acoustic density 286 $\mathrm{W} / \mathrm{L}, 1.26 \mathrm{~cm}^{2}$ titanium probe (keeping it at $3 \mathrm{~mm}$ depth in the samples). Also, the coconut water $(1700 \mathrm{~mL})$ was processed for 3 hours using an ultrasonic bath (UNIQUE, USC-1400 Model, Brazil) with a frequency of $40 \mathrm{kHz}$ and $28 \mathrm{~W} / \mathrm{L}$ of acoustic density. These conditions were selected after pre-evaluations. In order to control the process temperature $(23.7 \pm 2$ ${ }^{\circ} \mathrm{C}$ ), heat exchangers with cold water circulation were used. Along the processing period, samples of $3.5 \mathrm{~mL}$ were taken out in order to obtain the enzyme activity. All processes were carried out in three replicates.

The absolute ultrasonic power $\mathrm{P}(\mathrm{W})$ and acoustic energy density (W/L) was determined calorimetrically (Fonteles et al., 2012; O'Donnell et al., 2010). The ultrasonic energy consumption was calculated according $U_{e c}=P . t_{U S}(\mathrm{~J} / \mathrm{mL})$, where $t_{U S}$ is the ultrasound processing time.

\subsection{Enzyme activity evaluation}

The enzyme activity assays were determined in duplicate for each sample at $24 \pm 1{ }^{\circ} \mathrm{C}$ and $\mathrm{pH}$ 6.0. This condition was selected to be the optimum $\mathrm{pH}$ and temperature of the coconut water enzymes (Das Purkayastha et al., 2012; K. N. Matsui et al., 2007; Matsui et al., 2008; Murasaki-Aliberti et al., 2009; Tan et al., 2014a). The pH 6,0 was ensured using a buffer solution (McIlvaine's buffer), which was prepared using citric acid $\left(\mathrm{C}_{6} \mathrm{H}_{8} \mathrm{O}_{7}\right)$ (Synth, São Paulo) and sodium phosphate dibasic $\left(\mathrm{Na}_{2} \mathrm{HPO}_{4}\right)$ (Synth, São Paulo). For this purpose, a proportion of $1 \mathrm{~mL}$ of $\mathrm{C}_{6} \mathrm{H}_{8} \mathrm{O}_{7}(0.2 \mathrm{M}): 2.45 \mathrm{~mL}$ of $\mathrm{Na}_{2} \mathrm{HPO}_{4}(0.4$ $\mathrm{M})$ was mixed.

The POD activity was evaluated using pyrogallol $\left(\mathrm{C}_{6} \mathrm{H}_{6} \mathrm{O}_{3}\right)$ (Sigma-Aldrich, India) as the substrate as described by (Augusto et al., 2015; Falguera et al., 2013), with a few modifications. In each assay, $1.5 \mathrm{~mL}$ of coconut water, $1 \mathrm{~mL}$ of buffer solution at $\mathrm{pH} 6.0$ and $320 \mu \mathrm{L}$ of $5 \%$ $(\mathrm{m} / \mathrm{v})$ pyrogallol solution was mixed in a quartz cuvette with a $1 \mathrm{~cm}$ light path. The mixture of all reagents was used as reference solution (0.000 absorbance). Then, $160 \mu \mathrm{L}$ of hydrogen peroxide $\left(\mathrm{H}_{2} \mathrm{O}_{2}\right)$ (Synth, São Paulo) 0.147 M solution was added and mixed, which starts the reaction. The increase in the solution absorbance (Abs) at $420 \mathrm{~nm}$ was measured every $20 \mathrm{~s}$ for $10 \mathrm{~min}$ using a UV-Vis spectro- 
photometer (Uvmini-1240, SHIMADZU, Japan).

As described by (Augusto et al., 2015), the increase of absorbance at $420 \mathrm{~nm}$ in relation to the reaction time shows a downward concave shape curve, which could be described by a composite exponential function (Equation 1).

$A b s_{\left(t_{A b s}\right)}=A b s_{\infty}-\left(A b s_{\infty}-A b s_{0}\right) \cdot e^{\left(-k_{A b s} \cdot t_{A b s}\right)}$

Where: $A b s_{(t A b s)}$ is the sample absorbance at $420 \mathrm{~nm}$ at any time, $t_{A b s}, A b s_{0}$ is its initial absorbance, $A b s_{\infty}$ is the maximum absorbance at the equilibrium and $K_{A b s}$ is the kinetic parameter.

The enzyme activity $(A)$ was then defined as the maximum reaction rate, which is observed when $t_{A b s}=0$, thus being defined by:

$A=\left(\frac{d A b s\left(t_{A b s}\right)}{d t_{A b s}}\right)_{t_{A b s}=0}=\left(A b s_{\infty}-A b s_{0}\right) \cdot k_{A b s}(e q .2)$

The parameters for each model with a confidence level of $95 \%$ were obtained by regression using the Levenberg-Marquardt algorithm in Statistica 13 (StatSoft, USA) software. In order to obtain the kinetics of POD, the relative activity $\mathrm{A}$ (tus)/Ao was evaluated during the ultrasound processing time.

\section{Results and discussion}

All the previously studied methods have demonstrated an effective reduction of the enzyme activities in coconut water (conventional thermal process, ultrafiltration, additives addition, processing with microwave and ultraviolet radiation). However, the enzymes naturally present in coconut water showed a higher resistance when compared to those added to the sterilized medium or those added to model solutions (Augusto et al., 2015; Matsui et al., 2007).

Figure 1 shows the peroxidase (POD) residual activity of coconut water processed using the ultrasound bath and the ultrasound probe. It is observed that, at the same level of energy added to the system, both activation and inactivation were achieved, each one in one system.
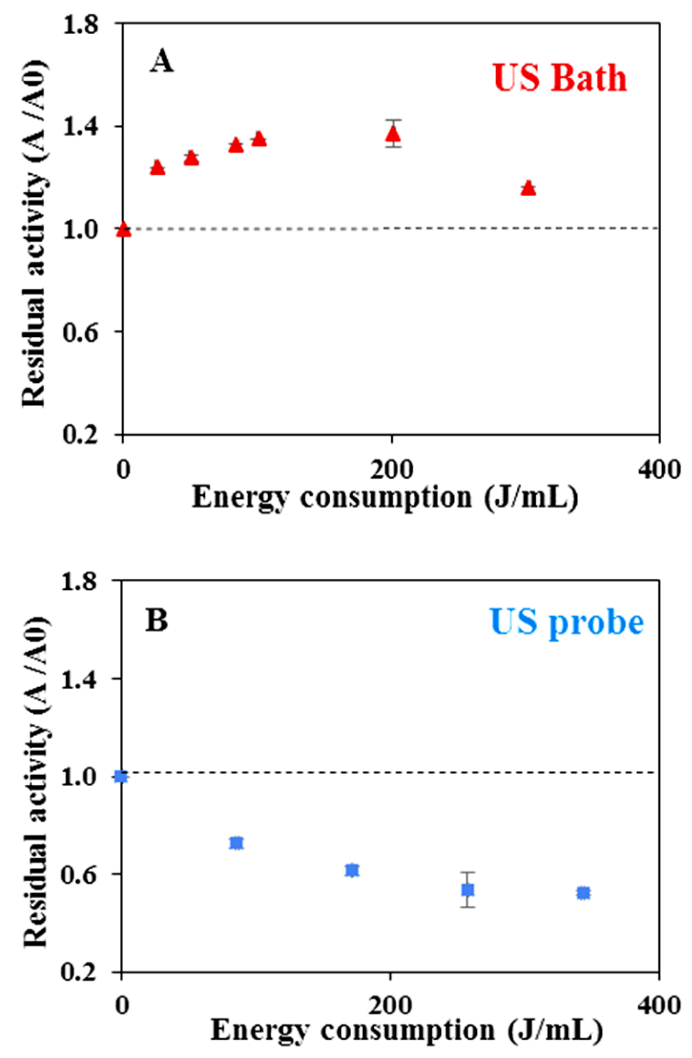

Figure 1. POD residual activity after ultrasound processing: process with ultrasound bath for $3 \mathrm{~h}(\mathrm{~A})$ and process with ultrasound probe for $20 \mathrm{~min}$ (B). Horizontal discontinuous line is the limit for being enzyme activation/inactivation. Vertical bars are the standard deviation $(\mathrm{p}=0.05)$.

The activation behaviour can be observed when high frequencies $(40 \mathrm{kHz}$ in the case of US bath) and low power (Wu y Lin, 2002) are used; therefore, long processing times $(>3 \mathrm{~h})$ are required to start inactivation. On the other hand, when low frequencies $(20 \mathrm{kHz}$ in the case of US probe) and high acoustic intensities were used, short times are required to achieve inactivation (and the activation period can be too short, that it is difficult to be seen). In fact, partial inactivation effects (i.e. the enzyme inactivation is not achieved completely) were reported by (Silva et al., 2015) in apple. Further, variations of increase or decrease in enzyme activity was observed under specific operating conditions (time, ultrasound intensity, temperature) (Engmann et al., 2014; 
Fonteles et al., 2012). For example, an increase in the enzyme activity was observed for POD with increasing processing time, and for PPO at higher temperatures $\left(60^{\circ} \mathrm{C}\right)$ in apple (Silva et al., 2015). On the other hand, PPO inactivation was reduced as ultrasonic frequency and treatment time were increased in mulberry (Engmann et al., 2014), indicating an inverse relationship. Therefore, a general conclusion cannot be specified, as the properties of both product $(\mathrm{pH}$, activity of water/vapour pressure, ionic strength, composition) and process (kind of equipment, volumetric power, frequency, intensity, amplitude, reactor geometry and waves distribution) influences the enzyme activity.

The ultrasonic mechanisms that change the enzyme activity are specific to the enzyme under investigation and depends on its amino acid composition and the conformational structure (Özbek and Ülgen, 2000). It is difficult to identify the specific enzyme inactivation mechanism during sonication, which could be due to a singular or combination of several chemical and physical effects occurring simultaneously (Rawson et al., 2011), resulting in multiple responses and possibilities. Table 1 reports the major factors that can affect the enzyme activity during ultrasonic processing. Since the enzyme have multiple responses, it is suggested that it can have infinite intermediate states (related with each spatial configuration associated with each value of internal energy of the system) during processing and that each intermediate state can result in an increase $\left(\mathrm{A} / \mathrm{A}_{0}>1\right)$, decrease $\left(\mathrm{A} / \mathrm{A}_{0}<1\right)$ or even the same $\left(\mathrm{A} / \mathrm{A}_{0}=1\right)$ activity.

\section{Table 1}

Major factors that can affect the enzyme activity during ultrasonic processing

\begin{tabular}{|c|c|}
\hline Ultrasound factor & \\
\hline \multirow{2}{*}{\multicolumn{2}{|c|}{$\begin{array}{l}\text { Mixing, particle collision, high shear rates and strong micro-streaming, ultrasonic waves propagation, } \\
\text { sample cavitation, severe rise in temperature and pressure, sonolysis of water molecules (Ercan y Soysal, } \\
\text { 2011; Terefe et al., 2009; Vercet et al., 2001). }\end{array}$}} \\
\hline & \\
\hline Possible effect & Activity response \\
\hline $\begin{array}{l}\text { Phenolic production as part of stress responses to a mechanical stimulus } \\
\text { (Wu y Lin, 2002). }\end{array}$ & - Increase \\
\hline - Collisions promotes enzyme - substrate contact. & - $\quad$ Increase \\
\hline - $\quad$ Activation of latent isoenzymes (Engmann et al., 2014). & - Increase \\
\hline - $\quad$ Dissociation of enzyme aggregates (López et al., 1994). & - Increase \\
\hline - $\quad$ Changes in the three-dimensional structure (Cruz et al., 2006). & - Increase/decrease \\
\hline $\begin{array}{l}\text { - Conformation changes in the active site three-dimensional structure, } \\
\text { enzyme-substrate interaction (Cruz et al., 2006). }\end{array}$ & - Increase/decrease \\
\hline $\begin{array}{l}\text { Molecular unfolding, causing the exposure of more hydrophobic groups } \\
\text { and regions from inside to the outside (Feng et al., 2016). }\end{array}$ & - $\quad$ Increase/decrease \\
\hline $\begin{array}{l}\text { Disruption of intra- and intermolecular substrate molecule interactions } \\
\text { (Barton et al., 1996). }\end{array}$ & - Increase/decrease \\
\hline - Inactivation of sensible isoenzymes fraction. & - $\quad$ Decrease \\
\hline $\begin{array}{l}\text { Splitting of prosthetic group of hemoproteins (Weissler, 1960); the same } \\
\text { could occur in holoenzymes (López et al., 1994), such as peroxidase. }\end{array}$ & - Decrease \\
\hline Protein denaturation (Terefe et al., 2009). & - $\quad$ Decrease \\
\hline
\end{tabular}


Then, the enzymes need energy $(\varepsilon)$ to pass from one to another state (Equation 3) and each energy quantum added to the system, results in a conformational change, which can change the enzyme activity. However, most of the works consider only two to four possibilities, which can be seen as a simplification (with good or bad description of the experimental data). Even so, it is important to expand the possibilities in order to better interpret the enzyme activity data.

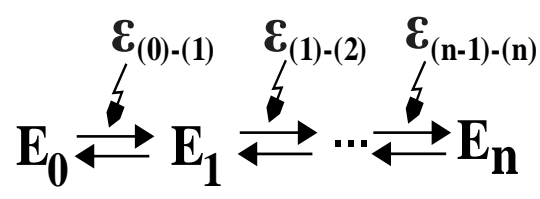

The results obtained in the present work suggest the applicability of the ultrasound technology to increase or decrease the enzyme activity. The increase in enzyme activity is desired in many industrial process which use enzymes for catalyse reactions such as to enhance the enzyme activities using supersaturated solutions (Lee et al., 2008), improve the enzymatic reaction rate (Barton et al., 1996; Sakakibara et al., 1996) and accelerate enzymatic synthesis (Xiao et al., 2005). In fact some recent studies used the ultrasound to improve the enzymatic efficiency such as in hydrolysis reactions by lipase (Waghmare y Rathod, 2016) where the ultrasound considerably reduced the reaction time as compared to conventional reaction, or to improve the enzymatic activity of immobilized papain (Feng et al., 2016). Consequently, the present work highlights the broad use of ultrasound technology for food processing.

\section{Conclusions}

Enzymes can present multiple states as response of processing. This complex behaviour depends on the system composition, enzyme conformation and processing properties. During ultrasonic processing, physical, mechanical or chemical factors directly affect the product and the three-dimensional structure of the enzyme. In this study, it was shown that the ultrasound technology has the ability to increase or decrease the enzyme activity, depending on the energy applied to the product, the frequency and other properties related with the ultrasound equipment design. This information can thus be exploited to both objectives (i.e. improving catalytic activity of enzymes or promote the inactivation and/or enzymatic sensitization), expanding the possible uses of ultrasound industrially.

\section{Acknowledgments}

The authors are grateful to the São Paulo Research Foundation (FAPESP, Brazil) for funding the project $n^{\circ} 2014 / 16998-3$ and, the JH Trevilin B.Sc scholarship (2015/15304-0), the National Council for Scientific and Technological Development (CNPq, Brazil) for funding the project $n^{\circ} 401004 / 2014-7$, and the Coordination for the Improvement of Higher Education Personnel (CAPES, Brazil) for the ML Rojas M.Sc. scholarship.

\section{References}

Abreu, L.; Faria, J. 2007. Influência da temperatura e do ácido ascórbico sobre a estabilidade físico-química e atividade enzimática da água de coco (Cocos nucifera L.) acondicionada assepticament. Food Science and Technology 27(2): 226-232.

Augusto, P.; Ibarz, R.; Garvín, A.; Ibarz, A. 2015. Peroxidase (POD) and polyphenol oxidase (PPO) photo-inactivation in a coconut water model solution using ultraviolet (UV). Food Research International 74: 151-159.

Barton, S.; Bullock, C.; Weir, D. 1996. The effects of ultrasound on the activities of some glycosidase enzymes of industrial importance. Enzyme and Microbial Technology 18(3): 190-194.

Costa, M.; Fonteles, T.; de Jesus, A.; Almeida, F.; de Miranda, M.; Fernandes, F.; Rodrigues, S. 2013. HighIntensity Ultrasound Processing of Pineapple Juice. Food and Bioprocess Technology 6(4): 997-1006.

Cruz, R.; Vieira, M.; Silva, C. 2006. Effect of heat and thermosonication treatments on peroxidase inactivation kinetics in watercress (Nasturtium officinale). Journal of Food Engineering 72(1): 8-15.

Das Purkayastha, M.; Kalita, D.; Mahnot, N.; Mahanta, C.; Mandal, M.; Chaudhuri, M. 2012. Effect of 1-ascorbic acid addition on the quality attributes of micro-filtered coconut water stored at $4{ }^{\circ} \mathrm{C}$. Innovative Food Science y Emerging Technologies 16: 69-79.

Engmann, F.; Ma, Y.; Tchabo, W.; Ma, H. 2014. Ultrasonication Treatment Effect on Anthocyanins, Color, Microorganisms and Enzyme Inactivation of Mulberry (Moraceae nigra) Juice. Journal of Food Processing and Preservation: n/a-n/a. 
Ercan, S.; Soysal, C. 2011. Effect of ultrasound and temperature on tomato peroxidase. Ultrasonics Sonochemistry 18(2): 689-695.

Falguera, V.; Moulin, A.; Thevenet, L.; Ibarz, A. 2013. Inactivation of Peroxidase by Ultraviolet-Visible Irradiation: Effect of $\mathrm{pH}$ and Melanoidin Content. Food and Bioprocess Technology 6(12): 3627-3633.

Feng, L.; Cao, Y.; Xu, D.; You, S.; Han, F. 2016. Influence of sodium alginate pretreated by ultrasound on papain properties: Activity, structure, conformation and molecular weight and distribution. Ultrasonics Sonochemistry 32: 224-230.

Fontan, R.; Alcântara, L.; Bonomo, R.; Fontan, G. 2012. Cinética de inativação da peroxidase em água de coco. Semina: Ciências Agrárias 33(1): 249-258.

Fonteles, T.; Costa, M.; de Jesus, A.; de Miranda, M.; Fernandes, F.; y Rodrigues, S. 2012. Power ultrasound processing of cantaloupe melon juice: Effects on quality parameters. Food Research International 48(1): 41-48.

Huang, N.; Cheng, X.; Hu, W.; Pan, S. 2015. Inactivation, aggregation, secondary and tertiary structural changes of germin-like protein in Satsuma mandarine with high polyphenol oxidase activity induced by ultrasonic processing. Biophysical Chemistry 197(2): 18-24.

Lee, S.; Nguyen, H.; Koo, Y.; y Ha, S. 2008. Ultrasoundenhanced lipase activity in the synthesis of sugar ester using ionic liquids. Process Biochemistry 43(9): 10091012.

López, P.; Sala, F.; De La Fuente, J.; Condón, S., Raso, J., Burgos, J. 1994. Inactivation of peroxidase, lipoxygenase, and polyphenol oxidase by manothermosonication. Journal of Agricultural and Food Chemistry 42(2): 252-256.

Matsui, K.; Granado, L.; de Oliveira, P.; Tadini, C. 2007. Peroxidase and polyphenol oxidase thermal inactivation by microwaves in green coconut water simulated solutions. LWT - Food Science and Technology 40(5): 852-859.

Matsui, K.; Gut, J.; de Oliveira, P.; Tadini, C. 2008. Inactivation kinetics of polyphenol oxidase and peroxidase in green coconut water by microwave processing. Journal of Food Engineering 88(2): 169176.

Murasaki-Aliberti, N.; Da Silva, R.; Gut, J.; Tadini, C.; 2009. Thermal inactivation of polyphenoloxidase and peroxidase in green coconut (Cocos nucifera) water. International Journal of Food Science y Technology, 44(12): 2662-2668.

Nakano, L.; Leal.Jr, W.; Freitas, D.; Cabral, L.; Penha, E.; Penteado, A.; Matta, V. 2011. Coconut water processing using ultrafiltration and pasteurization. Paper presented at the Proceeding of International Congress on Engineering and Food. National Technical University of Athens.

O’Donnell, C.; Tiwari, B.; Bourke, P.; Cullen, P. 2010. Effect of ultrasonic processing on food enzymes of industrial importance. Trends in Food Science y Technology 21(7): 358-367.

Pereira, E.; Faria, J.; Pinto, U.; 2013. Optimizing the use of potassium sorbate and sodium metabisulphite for the chemical and microbial stability of carbonated coconut water. Brazilian Journal of Food Technology 16: 125132.

Rawson, A.; Tiwari, B.; Patras, A.; Brunton, N.; Brennan, C.; Cullen, P.; O'Donnell, C. 2011. Effect of thermosonication on bioactive compounds in watermelon juice. Food Research International 44(5): 1168-1173.

Sakakibara, M.; Wang, D.; Takahashi, R.; Takahashi, K.; Mori, S. 1996. Influence of ultrasound irradiation on hydrolysis of sucrose catalyzed by invertase. Enzyme and Microbial Technology 18(6): 444-448.

Silva, L.; Almeida, P.; Rodrigues, S.; Fernandes, F. 2015. Inactivation of Polyphenoloxidase and Peroxidase in Apple Cubes and in Apple Juice Subjected to High Intensity Power Ultrasound Processing. Journal of Food Processing and Preservation, n/a-n/a.

Tan, T.; Cheng, L.; Bhat, R.; Rusul, G.; Easa, A. 2014a. Composition, physicochemical properties and thermal inactivation kinetics of polyphenol oxidase and peroxidase from coconut (Cocos nucifera) water obtained from immature, mature and overly-mature coconut. Food Chemistry 142: 121-128.

Tan, T.; Cheng, L.; Bhat, R.; Rusul, G.; Easa, A. 2014b. Composition, physicochemical properties and thermal inactivation kinetics of polyphenol oxidase and peroxidase from coconut (Cocos nucifera) water obtained from immature, mature and overly-mature coconut. Food Chemistry 142(1): 121-128.

Terefe, N.; Gamage, M.; Vilkhu, K.; Simons, L.; Mawson, R.; Versteeg, C. 2009. The kinetics of inactivation of pectin methylesterase and polygalacturonase in tomato juice by thermosonication. Food Chemistry 117(1): 2027.

Tiwari, B.; Muthukumarappan, K.; O'Donnell, C.; Cullen, P. 2009. Inactivation kinetics of pectin methylesterase and cloud retention in sonicated orange juice. Innovative Food Science y Emerging Technologies 10(2): 166-171.

Vercet, A.; Burgos, J.; Crelier, S.; Lopez-Buesa, P. 2001. Inactivation of proteases and lipases by ultrasound. Innovative Food Science y Emerging Technologies 2(2): 139-150.

Waghmare, G.; Rathod, V. 2016. Ultrasound assisted enzyme catalyzed hydrolysis of waste cooking oil under solvent free condition. Ultrasonics Sonochemistry 32: 60-67.

Weissler, A. 1960. Effects of Ultrasonic Irradiation on Hemoglobin. The Journal of the Acoustical Society of America 32(10): 1208-1212.

Wu, J.; Lin, L. 2002. Ultrasound-Induced Stress Responses of Panax ginsengCells: Enzymatic Browning and Phenolics Production. Biotechnology Progress 18(4): $862-866$

Xiao, Y.; Wu, Q.; Cai, Y.; Lin, X. 2005. Ultrasoundaccelerated enzymatic synthesis of sugar esters in nonaqueous solvents. Carbohydrate Research 340(13): 2097-2103.

Özbek, B.; Ülgen, K. 2000. The stability of enzymes after sonication. Process Biochemistry 35(9): 1037-1043. 